\title{
A Modular Synthesis of Tris(aryl)tren Ligands: Synthesis, Structure and Lithiation Chemistry
}

Velabo Mdluli, ${ }^{a}$ Patrick J. Hubbard, ${ }^{a}$ Diego R. Javier-Jimenez, ${ }^{a}$ Andrew Kuznicki, ${ }^{a}$ James A. Golen, ${ }^{a}$ Arnold L. Rheingold, ${ }^{b}$ David R. Manke ${ }^{* a}$

\footnotetext{
${ }^{a}$ Department of Chemistry and Biochemistry, University of Massachusetts Dartmouth, 285 Old Westport Road, North Dartmouth, MA 02747, USA

${ }^{b}$ Department of Chemistry, University of California, San Diego, 9500 Gilman Drive, La Jolla, CA 92093, USA
}

\section{*Corresponding Author:}

David R. Manke

dmanke@umassd.edu

$\mathrm{Ph}:(508) 910-6554$

Fax: (508)999-9167

285 Old Westport Rd, Violette 201B

North Dartmouth, MA 02747 


\begin{abstract}
A modular synthesis of tris(aryl)tren ligands has been demonstrated via the condensation of nitrilotracetyl chloride with different anilines followed by reduction. Varying the aniline in the condensation step from 2-methylthioaniline, to 2-phenylthioaniline, to 2-chloroaniline, generates 2,2',2'-nitrilotris(N-(2-(methylthio)phenyl)acetamide (1), 2,2',2"'-nitrilotris $(N-(2-$

(phenylthio)phenyl)acetamide (2) and 2,2',2"-nitrilotris( $N$-2-chlorophenyl)acetamide (3) respectively. The 2-chloroaniline synthesis is complicated by the production of $\mathrm{N}$-(2chlorophenyl)-3,5-dioxo-1-piperazine- $N$-(2-chlorophenyl)acetamide (4), but can be adjusted to produce only $\mathbf{3}$. The reduction of complexes $\mathbf{1 - 3}$ proceeds with lithium aluminum hydride for $\mathbf{1}$ and $\mathbf{2}$ and with borane for $\mathbf{3}$ to yield the tris(aryl)tren ligands tris-(2-(2(methylthio)phenylamino)ethyl)amine (5), tris-(2-(2-(phenylthio)phenylamino)ethyl)amine (6), and tris-(2-(2-chlorophenylamino)ethyl)amine (7). All three of these ligands can be deprotonated with tert-butyllithium for $\mathbf{5}$ and $\mathbf{7}$, and $n$-butyllithium for $\mathbf{6}$ to generate their trilithium complexes, 8, 9 and 10 for 5, 6 and 7 respectively, with 10 forming two different solvates (10a and 10b). All complexes are characterized by ${ }^{1} \mathrm{H}$ and ${ }^{13} \mathrm{C}$ NMR and the solid state structures of complexes $\mathbf{2}, \mathbf{3}$,
\end{abstract} 4, 7, 8, 9, 10a and $10 \mathrm{~b}$ are described. 


\section{Introduction}

The tris(2-aminoethyl)amine (tren) ligand and its derivatives have demonstrated a diverse coordination chemistry over the past 25 years [1-3]. The ligand set binds transition metals in the +3 oxidation state, with tetradentate $\mathrm{N} 4$ coordination and favors a $C_{3}$-symmetric environment around the metal center. Though many different variations of the tren ligand have been prepared, the majority of the metalation work performed to date has been on tris(silyl)tren derivatives [2,411]. The tris(aryl)tren ligand set has been explored to a lesser extent [12-19], but has shown great promise in the areas of nitrogen fixation [3] and in metal cluster formation [20].

Our lab has begun to explore the inclusion of sulfur moieties in the secondary coordination sphere of metals bound by tris(amido)amine ligands [21]. In a previous report, we described the synthesis of tris(2-methylthio)phenylamino)ethyl)amine (5), which starts with the conversion of nitrilotriacetic acid to nitrilotriacetyl chloride, proceeds via a coupling with 2-(methylthio)aniline and a standard reduction to the desired tren ligand. We sought to demonstrate that the general synthetic strategy could be expanded to other anilines, and that the synthesis of substituted tris(aryl)tren ligand could be performed in a modular way by simply altering the aniline used. Herein, we report he synthesis of two additional tris(aryl)tren ligands, and the deprotonation of all three ligands to form their trilithium complexes as synthetic tools for further metalation.

\section{Results and Discussion}

\subsection{Ligand Syntheses}

The synthesis of tris(2-X-phenylamino)ethyl)amine ligands proceeds via standard coupling and reduction techniques with nitrilotriacetic acid (NTA) as the starting material (Scheme 1). The NTA is first treated with phosphorus pentachloride to yield nitrilotriacetyl chloride [22]. The acid chloride is then coupled with 2-(methylthio)aniline or 2-(phenylthio)aniline using 
trimethylamine as a sacrificial base to yield 2,2',2"-nitrilotris $(N-(2-$

(methylthio)phenyl)acetamide (1), as previously reported [21], and 2,2',2"'-nitrilotris $(N-(2-$

(phenylthio)phenyl)acetamide (2). Following the same procedure with 2-chloroaniline generates a mixture (1:2) of 2,2',2"-nitrilotris( $N$-(2-chlorophenyl)acetamide (3) and $N$-2-chlorophenyl-3,5dioxo-1-piperazine- $N$-(2-chlorophenyl)acetamide (4) with an internal ring-closing favored over the substitution of the third arm [23]. The weaker 2-chloroaniline base is slower to attack the acid chloride, allowing the internal condensation reaction to occur where triethylamine acts as the sacrificial base. The desired compound (3) can be isolated in good yield and purity by using six equivalents of 2-chloroaniline such that it serves as both the reactant and the sacrificial base (Scheme 2).

The tris-amides can then be reduced to the desired tren ligands. The reduction of (1) and (2) proceeds with excess lithium aluminum hydride to generate the desire tris-(2-(2(methylthio)phenylamino)ethyl)amine (5), as we have previously reported [21], and tris-(2-(2(phenylthio)phenylamino)ethyl)amine (6). For the reduction of (3), borane was used as the reductant, to generate tris-(2-(2-chlorophenylamino)ethyl)amine (7). The ${ }^{1} \mathrm{H}$ and ${ }^{13} \mathrm{C}$ NMR for complexes $\mathbf{1}, \mathbf{2}, \mathbf{3}, \mathbf{5}, \mathbf{6}$, and $\mathbf{7}$ exhibit a single set of resonances that indicate the three arms are equivalent in solution. In a prior publication, we described the synthesis of the methylthio derivative, but have expanded the syntheses here to generate two new ligands by varying the aniline used. With only minor modifications, the synthesis should be modular and can be expanded to many other anilines, generating a variety of tris(aryl)tren ligands. Most commonly, ligands in this set have been synthesized via Buchwald couplings to tris(2-aminoethyl)amine [1517] rather than the coupling and reduction from the less expensive NTA.

\subsection{Ligand Structures}


The structure of (2) is shown in Figure 1. The three arms of the molecule are extended, with one intramolecular $(\mathrm{N} 2-\mathrm{H} 2 \cdots \mathrm{N} 1)$ and two intermolecular $(\mathrm{N} 3-\mathrm{H} 3 \cdots \mathrm{O} 2 ; \mathrm{N} 4-\mathrm{H} 4 \cdots \mathrm{O} 3)$ hydrogen bonds observed. The intermolecular hydrogen bonds join the molecules in an infinite chain along the $a$-axis. This structure is very similar to the structure of $(\mathbf{1})$, which we previously reported [21]. The solid state structure of (3) can be seen in Scheme 2. Like (2) it exhibits three extended arms in the molecule, with one 2-chlorophenyl group being disordered over two positions. There are also three hydrogen bonds observed, with one intramolecular $(\mathrm{N} 2-\mathrm{H} 2 \cdots \mathrm{O} 3)$ and two intermolecular $(\mathrm{N} 1-\mathrm{H} 1 \mathrm{~A} \cdots \mathrm{O} 2 ; \mathrm{N} 3-\mathrm{H} 3 \cdots \mathrm{O} 1)$. These interactions join the molecules in an infinite two-dimensional network along the (001) plane. Both molecules exhibit bond lengths and angles consistent with the parent nitrilotriacetanilide [24]. The side product of the 2chloroaniline reaction (4) shows two molecules in the asymmetric unit. Each molecule has an intramolecular $\mathrm{N}-\mathrm{H} \cdots \mathrm{N}$ hydrogen bond. One molecule has a rotational disorder with one chloride possessing partial occupancy over two positions. The molecule that does not exhibit a disorder is shown in Scheme 2. The solid state structure of the reduced chloro ligand (7) possesses a folded arrangement, which is similar to what is observed upon tripodal coordination of a metal center. This arrangement is similar to what we have observed previously for (5) and has been seen in other aryl substituted tren ligands [18,19,21,25].

\subsection{Lithiation Chemistry}

The lithiation of tren ligands to form their trilithium complexes has been reported for a number of tris(silyl)tren complexes [26-28]. The tris(aryl)tren ligands reported here can be deprotonated in a similar way with alkyl lithiums. The phenylthio derivative (6) can be deprotonated by treating it with three equivalents of $n$-butyllithium; the methylthio (5) and chloro (7) derivatives require the use of tert-butyllithium for clean deprotonation. The ${ }^{1} \mathrm{H}$ NMR of the methylthio 
trilithium complex (8) shows an integration that indicates three equivalents of tetrahydrofuran bound, while the ${ }^{1} \mathrm{H}$ NMR of the phenylthio trilithium complex (9) indicates that just two equivalents of tetrahydrofuran are bound. Varying the solvent of crystallization for the 2-chloro derivative from tetrahydrofuran to pentane leads to ${ }^{1} \mathrm{H}$ NMR that integrates to three equivalents of tetrahydrofuran (10a) or two equivalents of tetrahydrofuran $(\mathbf{1 0 b})$ respectively. The solid state structures of these compounds are consistent with these observations (vide infra).

\subsection{Lithium Structures}

The lithiated complex of the 2-methylthiophenyl(tren) derivative (8) exhibits crystallographically imposed $C_{3}$ symmetry, with only one arm of the tripodal ligand in the asymmetric unit. Each lithium atom is five coordinate bonding to two anilido nitrogens, one sulfur atom, the amine nitrogen and one tetrahydrofuran oxygen. This structural motif has not been previously reported, with all previous examples of trilithiated tren ligands exhibiting asymmetric coordination of the lithium atoms [29-31].

In moving to the bulkier 2-phenylthiophenyl(tren) derivative, only two tetrahydrofuran molecules bind in the complex. The compound has a planar $\mathrm{N}_{3} \mathrm{Li}_{3}$ arrangement with a deviation from planar of $0.121 \AA$. Two lithium ions are four coordinate, bound to two anilido nitrogens, one tetrahydrofuran oxygen and one sulfur atom. The third lithium ion is five coordinate, bound to all three anilido nitrogens, the one amino nitrogen and one sulfur atom. The $\mathrm{Li}-\mathrm{S}$ bond to the five coordinate lithium ion is significantly longer than to the four coordinate lithium ions (2.733(6) $\AA$ vs. 2.510(6) $\AA$ and 2.542(6) $\AA$ ). The structure is similar to that observed for the trilithium complex of the trimethylsilyl tren ligand [30].

The 2-chlorophenyl(tren) derivative crystallizes in two forms, with crystals grown from a tetrahydrofuran solution demonstrating a structure equivalent to $\mathbf{8}$, with crystallographically 
imposed $C_{3}$ symmetry and three tetrahydrofuran solvent molecules bound. When crystals are grown from a pentane solution, the complex only has two coordinated tetrahydrofuran molecules with a structure analogous to 9 . This structure possesses a planar $\mathrm{N}_{3} \mathrm{Li}_{3}$ arrangement with a deviation from planar of $0.134 \AA$ A. In both instances, there are $\mathrm{Li} \cdots \mathrm{Cl}$ interactions, with distances ranging from 2.489(4) $\AA$ to 2.702(4) $\AA$.

\section{Conclusions}

The two-step synthesis with an aniline coupling and a standard reduction starting from nitrilotriacetic acid is a versatile avenue to a variety of tris(aryl)tren ligands. The general approach should be broadly applicable to other anlines, generating tris(aryl)tren ligands with many different substitution patterns. The unexpected complications in the 2-chloroaniline synthesis provide an opportunity to generate asymmetric tren ligands from the side product (4), which we have begun to examine. We are also exploring the 2-chloroaniline derivative for further modification, through substitution and derivatization at the chloro position. The ligands can be readily lithiated, providing a useful synthon to further metalate the system. In future publications, we will explore the coordination chemistry of these three ligands with transition metals.

\section{Experimental}

\subsection{General Considerations}

All organic manipulations were carried out using standard Schlenk techniques and lithiations were performed in a nitrogen glovebox unless otherwise noted. Pentane, tetrahydrofuran, toluene and benzene- $d_{6}$ were all dried over sodium/benzophenone and distilled prior to use. Chloroform$d$ was dried over calcium sulfate, distilled and stored over $3 \AA$ molecular sieves. All other solvents and chemicals were used as purchased without further purification. NMR spectra were 
recorded on a Bruker AVANCE III HD $400 \mathrm{MHz}$ instrument. ${ }^{1} \mathrm{H}$ and ${ }^{13} \mathrm{C}$ NMR chemical shifts were referenced to residual solvent. $2,2^{\prime}, 2^{\prime \prime}$-nitrilotriacetylchloride was prepared according to literature procedure [32]. Compounds $\mathbf{1}$ and $\mathbf{5}$ were also reported previously [21]. Elemental analyses were carried out at Robertson Microlit Laboratories in Ledgewood, NJ.

\subsection{X-ray crystallography}

All operations were performed on a Bruker D8 Venture CMOS diffractometer or a Bruker Apex2 CCD diffractometer. Data collection was carried out using the Bruker APEX2 software. Cell refinement and data reduction were performed with the SAINT program [33]. The structure solution was done with SHELXS97 [34] and structure refinement was performed with SHELXL2014 [35]. Further refinement and molecular graphics were generated using the OLEX2 software [36]. Crystallographic data and refinement parameters are included in Table 1 with more detailed information available in the supplementary material.

\subsection{Synthesis of 2,2',2"-Nitrilotris(N-(2-(phenylthio)phenyl)acetamide),} $\mathrm{N}\left(\mathrm{CH}_{2} \mathrm{CONHC}_{6} \mathrm{H}_{4} \mathrm{SC}_{6} \mathrm{H}_{5}\right)_{3}(2)$

To a cooled $\left(0^{\circ} \mathrm{C}\right) 100 \mathrm{~mL}$ THF solution of 2,2' 2"-nitrilotriacetyl chloride $(3.34 \mathrm{~g}, 13.6 \mathrm{mmol})$ was added a mixture of 2-phenylthioaniline $(8.46 \mathrm{~g}, 42.0 \mathrm{mmol})$ and trimethylamine $(5.85 \mathrm{~mL}$, $42.0 \mathrm{mmol}$ ) dropwise over the course of 15 minutes. The resulting mixture was allowed to warm to room temperature, stirred for 12 hours, filtered and solvent removed in vacuo. The resulting oil was dissolved in dichloromethane $(100 \mathrm{~mL})$ and extracted with water $(3 \times 100 \mathrm{~mL})$. The organic layer was dried with anhydrous sodium sulfate, filtered and solvent removed in vacuo. The product was triturated with a minimal amount of ethanol, filtered and washed with pentane to afford a white solid of $2(7.82 \mathrm{~g}, 78 \%) .{ }^{1} \mathrm{H}$ NMR $\left(400 \mathrm{MHz}, \mathrm{CDCl}_{3}\right): \delta 8.90(\mathrm{~s}, 3 \mathrm{H}, \mathrm{NH}), 8.28$ $(\mathrm{d}, J=8.04 \mathrm{~Hz}, 3 \mathrm{H}, \operatorname{Ar} H), 7.51(\mathrm{~d}, J=7.6 \mathrm{~Hz}, 3 \mathrm{H}, \operatorname{Ar} H), 7.42(\mathrm{t}, J=7.6 \mathrm{~Hz}, 3 \mathrm{H}, \operatorname{Ar} H), 7.13(\mathrm{t}, J$ 
$=7.3 \mathrm{~Hz}, 9 \mathrm{H}, \mathrm{Ar} H), 7.05(\mathrm{~m}, 3 \mathrm{H}, \mathrm{ArH}), 6.95(\mathrm{~d}, J=7.6 \mathrm{~Hz}, 6 \mathrm{H}, \mathrm{Ar} H), 3.18\left(\mathrm{~s}, 6 \mathrm{H}, \mathrm{CH}_{2}\right) ;{ }^{13} \mathrm{C}$

NMR (100 MHz, $\left.\mathrm{CDCl}_{3}\right): \delta 167.8(C \mathrm{O}), 139.1(\operatorname{ArC}), 136.2(\operatorname{ArC}), 135.9(\operatorname{ArC}) 130.7(\operatorname{ArC})$,

129.3 (2 $\mathrm{ArC}), 127.1(2 \mathrm{ArC}), 126.2(\operatorname{ArC}), 125.1(\operatorname{ArC}), 121.8(\operatorname{ArC}), 121.2(\operatorname{ArC}), 58.3\left(\mathrm{CH}_{2}\right)$.

Elemental analysis calcd. for $\mathrm{C}_{42} \mathrm{H}_{36} \mathrm{~N}_{4} \mathrm{O}_{3} \mathrm{~S}_{3}$ : C 68.08, H 4.90, N 7.56; Found: $\mathrm{C} 68.33, \mathrm{H}$ 4.86, N 7.47.

4.4. Synthesis of 2,2',2"-nitrilotris( $\mathrm{N}$-(2-(chloro)phenyl)acetamide), $\mathrm{C}_{24} \mathrm{H}_{21} \mathrm{Cl}_{3} \mathrm{~N}_{4} \mathrm{O}_{3}(\mathbf{3})$

To a cooled $\left(0^{\circ} \mathrm{C}\right) 100 \mathrm{~mL}$ THF solution of 2,2',2"-nitrilotriacetyl chloride (2.98 g, $\left.12.1 \mathrm{mmol}\right)$ was added 2-chloroaniline $(7.90 \mathrm{~mL}, 75.1 \mathrm{mmol})$ dropwise over the course of 15 minutes. The resulting mixture was allowed to warm to room temperature, stirred for 12 hours, filtered and solvent removed in vacuo. The resulting oil was dissolved in dichloromethane $(100 \mathrm{~mL})$ and extracted with water $(3 \times 100 \mathrm{~mL})$. The organic layer was dried with anhydrous sodium sulfate, filtered and solvent removed in vacuo. The product was triturated with a minimal amount of ethanol, filtered and washed with pentane to afford a white solid of $\mathbf{3}(5.21 \mathrm{~g}, 83 \%)$. ${ }^{1} \mathrm{H}$ NMR $\left(400 \mathrm{MHz}, \mathrm{CDCl}_{3}\right): \delta 8.79$ (s, $\left.3 \mathrm{H}, \mathrm{OCNH}\right), 8.30(\mathrm{~d}, J=8.2 \mathrm{~Hz}, 3 \mathrm{H}, \mathrm{Ar} H), 7.36(\mathrm{~d}, J=8.0 \mathrm{~Hz}$, 3H, $\mathrm{ArH}), 7.28(\mathrm{~m}, 3 \mathrm{H}, \mathrm{Ar} H), 7.07(\mathrm{t}, J=7.4 \mathrm{~Hz}, 3 \mathrm{H}, \mathrm{Ar} H), 3.72\left(\mathrm{~s}, 6 \mathrm{H}, \mathrm{CH}_{2}\right) ;{ }^{13} \mathrm{C}$ NMR $(100$ $\left.\mathrm{MHz}, \mathrm{CDCl}_{3}\right): \delta 167.9(\mathrm{CO}), 134.0(\mathrm{ArC}), 129.2(\mathrm{ArC}), 127.7(\mathrm{ArC}), 125.4(\operatorname{ArC}), 122.5(\operatorname{ArC})$, $59.5\left(\mathrm{CH}_{2}\right)$. Elemental analysis calcd. for $\mathrm{C}_{24} \mathrm{H}_{21} \mathrm{Cl}_{3} \mathrm{~N}_{4} \mathrm{O}_{3}$ : C 55.46, H 4.07, N 10.78; Found: $\mathrm{C}$ 55.54, H 4.13, N 10.41.

4.5. Synthesis of N-(2-chlorophenyl)-3,5-dioxo-1-piperazine-N-(2-chlorophenyl)acetamide, $\mathrm{C}_{18} \mathrm{H}_{15} \mathrm{Cl}_{2} \mathrm{~N}_{3} \mathrm{O}_{3}(4)$

To a cooled $\left(0^{\circ} \mathrm{C}\right) 100 \mathrm{~mL}$ THF solution of 2, 2', 2"-nitrilotriacetyl chloride (3.61 g, $\left.14.6 \mathrm{mmol}\right)$ was added a mixture of 2-chloroaniline $(4.80 \mathrm{~mL}, 45.6 \mathrm{mmol})$ and trimethylamine $(6.40 \mathrm{~mL}$, $45.9 \mathrm{mmol}$ ) dropwise over the course of 15 minutes. The resulting mixture was allowed to warm 
to room temperature, stirred for 12 hours, filtered and solvent was removed in vacuo. The resulting oil was dissolved in dichloromethane $(100 \mathrm{~mL})$ and extracted with water $(3 \times 100 \mathrm{~mL})$. The organic layer was dried with anhydrous sodium sulfate, filtered and solvent removed in vacuo. The crude product was triturated with a minimal amount of ethanol, filtered and washed with pentane to afford a white solid of a mixture of $\mathbf{4}$ and $\mathbf{3}$ (ratio 2:1). The mixture was dissolved in hot toluene and left to cool overnight to crash out the crystals of $4(1.49 \mathrm{~g}, 26 \%) .{ }^{1} \mathrm{H}$ NMR (400 MHz, CDCl $)$ ): $\delta 9.37(\mathrm{~s}, 1 \mathrm{H}, \mathrm{NH}), 8.37(\mathrm{dd}, J=8.2 \mathrm{~Hz}, 1.3 \mathrm{~Hz}, 1 \mathrm{H}, \mathrm{Ar} H), 7.54(\mathrm{~m}$, 1H, $\operatorname{Ar} H), 7.38(\mathrm{~m}, 3 \mathrm{H}, \operatorname{Ar} H), 7.29(\mathrm{dt}, J=7.8 \mathrm{~Hz}, 1.2 \mathrm{~Hz}, 1 \mathrm{H}, \operatorname{Ar} H), 7.19(\mathrm{~m}, 1 \mathrm{H}, \operatorname{Ar} H), 7.07$ (dt, $J=7.9 \mathrm{~Hz}, 1.5 \mathrm{~Hz}, 1 \mathrm{H}, \mathrm{Ar} H), 3.80\left(\mathrm{q}, J=17 \mathrm{~Hz}, 4 \mathrm{H}, \mathrm{CH}_{2}\right), 3.46\left(\mathrm{~s}, 2 \mathrm{H}, \mathrm{CH}_{2}\right) ;{ }^{13} \mathrm{C}$ NMR $\left(100 \mathrm{MHz}, \mathrm{CDCl}_{3}\right): \delta 168.0(2 \mathrm{CO}), 165.9(\mathrm{CO}), 133.9(\mathrm{ArC}), 132.6(\mathrm{ArC}), 131.2(\mathrm{ArC}), 130.9$ (ArC), $130.4(2 \operatorname{ArC}), 129.2(\operatorname{ArC}), 128.0(2 \operatorname{ArC}), 125.3(\operatorname{ArC}), 123.4(\operatorname{ArC}), 121.5(\operatorname{ArC}), 59.8$ $\left(\mathrm{CH}_{2}\right)$, $56.7\left(2 \mathrm{CH}_{2}\right)$. Elemental analysis calcd. for $\mathrm{C}_{18} \mathrm{H}_{15} \mathrm{Cl}_{2} \mathrm{~N}_{3} \mathrm{O}_{3}$ : C 55.12, H 3.85, N 10.71; Found: C 55.21, H 3.87, N 10.60

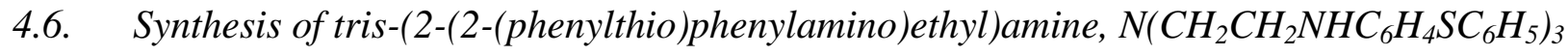
(6)

To a cooled $\left(0{ }^{\circ} \mathrm{C}\right) 100 \mathrm{~mL}$ solution of $(2)(4.31 \mathrm{~g}, 5.82 \mathrm{mmol})$ was added $\mathrm{LiAlH}_{4}(2.21 \mathrm{~g}, 58.2$ mmol) in 10 parts. The reaction was heated to reflux for 12 hours, then cooled to $0{ }^{\circ} \mathrm{C}$ and quenched with $20 \mathrm{~mL}$ of water. A solution of $\mathrm{NaOH}(20 \%$ w/w, $30 \mathrm{~mL})$ was added and reaction mixture stirred for 1 hour, filtered, the residue was washed with THF $(50 \mathrm{~mL})$ and the filtrate was stripped of solvent in vacuo. The resulting oil was dissolved in dichloromethane $(100 \mathrm{~mL})$, extracted with water $(3 \times 100 \mathrm{~mL})$. The organic layer was dried with anhydrous sodium sulfate, and solvent was removed in vacuo. Analytically pure product was obtained by column chromatography on silica gel (dichloromethane:hexanes, 3:1) to give a yellow oil of $\mathbf{6}$ after 
dryness (1.72 g, 42\%). ${ }^{1} \mathrm{H}$ NMR (400 MHz, $\left.\mathrm{CDCl}_{3}\right): \delta 7.45(\mathrm{dd}, J=7.6 \mathrm{~Hz}, 1.5 \mathrm{~Hz}, 3 \mathrm{H}, \mathrm{ArH})$, $7.25(\mathrm{dt}, J=7.7 \mathrm{~Hz}, 1.5 \mathrm{~Hz}, 3 \mathrm{H}, \mathrm{Ar} H), 7.10(\mathrm{t}, J=7.5 \mathrm{~Hz}, 6 \mathrm{H}, \mathrm{Ar} H), 7.0(\mathrm{~m}, 9 \mathrm{H}, \mathrm{Ar} H), 6.67$ (dt, $J=7.5 \mathrm{~Hz}, 1.0 \mathrm{~Hz}, 3 \mathrm{H}, \operatorname{Ar} H), 6.52(\mathrm{~d}, J=8.2 \mathrm{~Hz}, 3 \mathrm{H}, \mathrm{ArH}), 5.11(\mathrm{t}, J=4.9 \mathrm{~Hz}, 3 \mathrm{H}, \mathrm{NH}), 2.94$ $\left(\mathrm{q}, J=6.0 \mathrm{~Hz}, 6 \mathrm{H}, \mathrm{CH}_{2}\right), 2.47\left(\mathrm{t}, J=6.5 \mathrm{~Hz}, 6 \mathrm{H}, \mathrm{CH}_{2}\right) ;{ }^{13} \mathrm{C} \mathrm{NMR}\left(100 \mathrm{MHz}, \mathrm{CDCl}_{3}\right): \delta 149.3$ $(\mathrm{ArC}), 137.7(\mathrm{ArC}), 137.0(\mathrm{ArC}), 131.4(\mathrm{ArC}), 128.8(2 \mathrm{ArC}), 126.2(2 \mathrm{ArC}), 125.2(\mathrm{ArC}), 116.9$ (ArC), $113.9(\mathrm{ArC}), 110.6(\mathrm{ArC}), 53.4\left(\mathrm{CH}_{2}\right), 41.6\left(\mathrm{CH}_{2}\right)$. Elemental analysis calcd. for $\mathrm{C}_{42} \mathrm{H}_{42} \mathrm{~N}_{4} \mathrm{~S}_{3}$ : C 72.17, H 6.06, N 8.02; Found: C 72.26, H 6.17, N 7.81.

\subsection{Synthesis of tris-(2-(2-(chloro)phenylamino)ethyl)amine, $\mathrm{N}\left(\mathrm{CH}_{2} \mathrm{CH}_{2} \mathrm{NHC}_{6} \mathrm{H}_{4} \mathrm{Cl}\right)_{3}(7)$}

To a cooled $\left(0{ }^{\circ} \mathrm{C}\right) 100 \mathrm{~mL}$ solution of $(3)(2.44 \mathrm{~g}, 4.69 \mathrm{mmol})$ was added $\mathrm{BH}_{3} \cdot \mathrm{THF}(1 \mathrm{M}$ in THF, $47 \mathrm{~mL}, 47 \mathrm{mmol}$ ) dropwise over 20 minutes. The reaction was heated to reflux for 12 hours, then cooled to $0{ }^{\circ} \mathrm{C}$. The solution was treated slowly with a solution of aqueous $1 \mathrm{M} \mathrm{HCl}$ (20 mL), heated to reflux for 3 hours, then cooled to $0{ }^{\circ} \mathrm{C}$ and $4 \mathrm{M} \mathrm{NaOH}$ solution added until $\mathrm{pH}>8$. The THF was removed in vacuo and aqueous layer extracted with dichloromethane $(3 \times$ $50 \mathrm{~mL}$ ). The combine organic fractions were dried with anhydrous sodium sulfate, filtered and solvent removed in vacuo. The product was triturated with a minimal amount of ethanol, filtered and washed with pentane to afford a white solid of 7 (1.75 g, 78\%). ${ }^{1} \mathrm{H}$ NMR (400 MHz, $\left.\mathrm{CDCl}_{3}\right)$ : $\delta 7.16(\mathrm{dd}, J=7.7 \mathrm{~Hz}, 1.4 \mathrm{~Hz}, 3 \mathrm{H}, \mathrm{ArH}), 7.08(\mathrm{dt}, J=7.8 \mathrm{~Hz}, 1.3 \mathrm{~Hz}, 3 \mathrm{H}, \mathrm{ArH}), 6.61(\mathrm{~m}, 6 \mathrm{H}$, $\operatorname{ArH}), 4.71(\mathrm{t}, J=4.8 \mathrm{~Hz}, 3 \mathrm{H}, \mathrm{NH}), 3.27\left(\mathrm{q}, J=5.9 \mathrm{~Hz}, 6 \mathrm{H}, \mathrm{CH}_{2}\right), 2.87\left(\mathrm{t}, J=5.1 \mathrm{~Hz}, 6 \mathrm{H}, \mathrm{CH}_{2}\right)$; ${ }^{13} \mathrm{C}$ NMR (100 MHz, $\left.\mathrm{CDCl}_{3}\right): \delta 143.8(\mathrm{ArC}), 129.1$ (ArC), $127.7(\mathrm{ArC}), 119.4(\mathrm{ArC}), 117.3$ $(\mathrm{ArC}), 111.2(\mathrm{ArC}), 53.7\left(\mathrm{CH}_{2}\right), 41.6\left(\mathrm{CH}_{2}\right)$. Elemental analysis calcd. for $\mathrm{C}_{24} \mathrm{H}_{27} \mathrm{Cl}_{3} \mathrm{~N}_{4}$ : C 60.32, H 5.70, N 11.72; Found: C 60.17, H 5.61, N 11.56.

4.8. Synthesis of $\mathrm{Li}_{3}\left[\mathrm{C}_{27} \mathrm{H}_{33} \mathrm{~N}_{4} \mathrm{~S}_{3}\right](\mathrm{THF})_{3}(\mathbf{8})$ 
A solution of 5 (590 mg, $1.15 \mathrm{mmol})$ in THF (3 mL) was frozen with liquid nitrogen, and tertbutyllithium (1.7 $\mathrm{M}$ in pentane, $2.30 \mathrm{~mL}, 3.91 \mathrm{mmol})$ was added dropwise as the solution thawed. The mixture was stirred for 2 hours at room temperature. Pentane $(10 \mathrm{~mL})$ was added to precipitate out a white solid which was isolated via vacuum filtration and washed with additional pentane $(2 \times 10 \mathrm{~mL})$ to give the desired product $(771 \mathrm{mg}, 90 \%) .{ }^{1} \mathrm{H} \mathrm{NMR}\left(400 \mathrm{MHz}, \mathrm{CDCl}_{3}\right): \delta$ $7.28(\mathrm{~d}, J=6.6 \mathrm{~Hz}, 3 \mathrm{H}, \operatorname{Ar} H), 7.21(\mathrm{t}, J=7.6 \mathrm{~Hz}, 3 \mathrm{H}, \operatorname{Ar} H), 6.56(\mathrm{~m}, 3 \mathrm{H}, \operatorname{Ar} H), 3.35$ (br s, 12H, $\mathrm{CH}_{2}, \mathrm{THF}$ ), 3.23 (br s, 6H, $\mathrm{CH}_{2}$ ), 2.76 (br s, 6H, CH ), 1.94 (s, 9H, $\mathrm{CH}_{3}$ ), 1.19 (br s, 12H, $\mathrm{CH}_{2}$, THF). ${ }^{13} \mathrm{C}$ NMR (100 MHz, $\left.\mathrm{CDCl}_{3}\right): \delta 161.6(\mathrm{ArC}), 131.2(\mathrm{ArC}), 128.9(\mathrm{ArC}), 123.9(\mathrm{ArC})$, 112.1 (ArC), $111.2(\mathrm{ArC}), 69.0\left(\mathrm{CH}_{2}, \mathrm{THF}\right), 54.1\left(\mathrm{CH}_{2}\right), 48.2\left(\mathrm{CH}_{2}\right), 25.7\left(\mathrm{CH}_{2}, \mathrm{THF}\right), 18.7$ $\left(\mathrm{CH}_{3}\right)$.

\subsection{Synthesis of $\mathrm{Li}_{3}\left[\mathrm{C}_{42} \mathrm{H}_{39} \mathrm{~N}_{4} \mathrm{~S}_{3}\right](\mathrm{THF})_{2}(\mathbf{9})$}

A solution of $6(700 \mathrm{mg}, 1.0 \mathrm{mmol})$ in THF (3 mL) was frozen with liquid nitrogen, and $n$ butyllithium (2.5 $\mathrm{M}$ in hexanes, $1.24 \mathrm{~mL}, 3.10 \mathrm{mmol})$ was added dropwise as the solution thawed. The mixture was stirred for 2 hours at room temperature. Pentane $(10 \mathrm{~mL})$ was added to precipitate out a yellow solid which was isolated via vacuum filtration and washed with additional pentane $(2 \times 10 \mathrm{~mL})$ to give the desired product $(789 \mathrm{mg}, 92 \%) .{ }^{1} \mathrm{H} \mathrm{NMR}(400 \mathrm{MHz}$, $\left.\mathrm{CDCl}_{3}\right): \delta 7.41(\mathrm{~d}, J=7.2 \mathrm{~Hz}, 3 \mathrm{H}, \mathrm{Ar} H), 7.18(\mathrm{~m}, 3 \mathrm{H}, \mathrm{ArH}), 7.01(\mathrm{~d}, J=7.6 \mathrm{~Hz}, 6 \mathrm{H}, \mathrm{ArH}), 6.88$ $(\mathrm{t}, J=7.2 \mathrm{~Hz}, 6 \mathrm{H}, \operatorname{Ar} H), 6.77(\mathrm{~m}, 3 \mathrm{H}, \operatorname{Ar} H), 6.54(\mathrm{~d}, J=8.2 \mathrm{~Hz}, 3 \mathrm{H}, \operatorname{Ar} H), 6.48(\mathrm{t}, J=7.2 \mathrm{~Hz}$, 3H, $\mathrm{ArH}$ ), 3.11 (br s, 6H, $\mathrm{CH}_{2}$ ), 2.97 (br s, 8H, $\mathrm{CH}_{2}, \mathrm{THF}$ ), 2.64 (br s, 6H, $\mathrm{CH}_{2}$ ), 0.94 (br s, 8H, $\left.\mathrm{CH}_{2}, \mathrm{THF}\right) .{ }^{13} \mathrm{C} \mathrm{NMR}\left(100 \mathrm{MHz}, \mathrm{CDCl}_{3}\right): \delta 162.6(\mathrm{ArC}), 138.6(2 \mathrm{ArC}), 136.0(2 \mathrm{ArC}), 130.3$ $(\mathrm{ArC}), 128.3(\mathrm{ArC}), 127.2(\mathrm{ArC}), 124.6(\mathrm{ArC}), 116.7(\mathrm{ArC}), 112.4(\mathrm{ArC}), 111.9(\mathrm{ArC}), 68.7$ $\left(\mathrm{CH}_{2}, \mathrm{THF}\right), 53.9\left(\mathrm{CH}_{2}\right), 48.0\left(\mathrm{CH}_{2}\right), 25.5\left(\mathrm{CH}_{2}, \mathrm{THF}\right)$.

\subsection{Synthesis of $\mathrm{Li}_{3}\left[\mathrm{C}_{24} \mathrm{H}_{24} \mathrm{~N}_{4} \mathrm{Cl}_{3}\right](\mathrm{THF})_{3}$ (10a)}


A solution of 7 (717 mg, $1.50 \mathrm{mmol})$ in THF ( $3 \mathrm{~mL})$ was frozen with liquid nitrogen and tertbutyllithium (1.7 M in pentane, $3.5 \mathrm{~mL}, 6.0 \mathrm{mmol}$ ) was added dropwise as the solution thawed. The mixture was stirred for 2 hours at room temperature. Pentane $(10 \mathrm{~mL})$ was added to precipitate out a yellow solid which was isolated via vacuum filtration and washed with additional pentane $(2 \times 10 \mathrm{~mL})$ to give the desire product $(943 \mathrm{mg}, 88 \%) .{ }^{1} \mathrm{H} \mathrm{NMR}(400 \mathrm{MHz}$, $\left.\mathrm{CDCl}_{3}\right): \delta 7.28(\mathrm{~d}, J=7.6 \mathrm{~Hz}, 3 \mathrm{H}, \mathrm{Ar} H), 7.19(\mathrm{~m}, 3 \mathrm{H}, \mathrm{Ar} H), 6.60(\mathrm{~d}, J=7.9 \mathrm{~Hz}, 3 \mathrm{H}, \mathrm{Ar} H), 6.37$ (d, $J=7.9 \mathrm{~Hz}, 3 \mathrm{H}, \mathrm{ArH}$ ), 3.23 (br s, $12 \mathrm{H}, \mathrm{CH}_{2}, \mathrm{THF}$ ), 3.16 (br s, 6H, $\mathrm{CH}_{2}$ ), 2.67 (br s, 6H, $\mathrm{CH}_{2}$ ), $1.12\left(\mathrm{t}, J=6.2 \mathrm{~Hz}, 12 \mathrm{H}, \mathrm{CH}_{2}, \mathrm{THF}\right) .{ }^{13} \mathrm{C} \mathrm{NMR}\left(100 \mathrm{MHz}, \mathrm{CDCl}_{3}\right): \delta 157.6(\mathrm{ArC}), 128.8(2$ $\operatorname{ArC}), 122.2(\operatorname{ArC}), 113.0(\operatorname{ArC}), 111.9(\mathrm{ArC}), 68.7\left(\mathrm{CH}_{2}\right.$, THF), $53.7\left(\mathrm{CH}_{2}\right), 47.5\left(\mathrm{CH}_{2}\right), 25.6$ $\left(\mathrm{CH}_{2}, \mathrm{THF}\right)$.

\subsection{Synthesis of $\mathrm{Li}_{3}\left[\mathrm{C}_{24} \mathrm{H}_{24} \mathrm{~N}_{4} \mathrm{Cl}_{3}\right](\mathrm{THF})_{2}(\mathbf{1 0 b})$}

The same preparative procedure was followed as for 10a, but crystals were isolated from a pentane solution. ${ }^{1} \mathrm{H}$ NMR (400 MHz, $\left.\mathrm{CDCl}_{3}\right): \delta 7.27(\mathrm{dd}, J=8.0 \mathrm{~Hz}, 1.6 \mathrm{~Hz}, 3 \mathrm{H}, \mathrm{Ar} H), 7.16$ (m, 3H, ArH), $6.60(\mathrm{~d}, J=8.0 \mathrm{~Hz}, 3 \mathrm{H}, \operatorname{Ar} H), 6.37(\mathrm{t}, J=7.2 \mathrm{~Hz}, 3 \mathrm{H}, \operatorname{Ar} H), 3.13(\mathrm{t}, J=4.8 \mathrm{~Hz}$, $6 \mathrm{H}, \mathrm{CH}_{2}$ ), 3.06 (t, $\left.\mathrm{J}=4.8 \mathrm{~Hz}, 8 \mathrm{H}, \mathrm{CH}_{2}, \mathrm{THF}\right), 2.63\left(\mathrm{~m}, 6 \mathrm{H}, \mathrm{CH}_{2}\right), 0.98\left(\mathrm{~m}, 8 \mathrm{H}, \mathrm{CH}_{2}, \mathrm{THF}\right) .{ }^{13} \mathrm{C}$ NMR (100 MHz, $\left.\mathrm{CDCl}_{3}\right): \delta 157.5(\operatorname{ArC}), 129.0(\mathrm{ArC}), 128.8(\mathrm{ArC}), 122.4(\mathrm{ArC}), 113.1(\mathrm{ArC})$, 112.3 ( $\mathrm{ArC}), 68.8\left(\mathrm{CH}_{2}, \mathrm{THF}\right), 53.7\left(\mathrm{CH}_{2}\right), 47.6\left(\mathrm{CH}_{2}\right), 25.4\left(\mathrm{CH}_{2}, \mathrm{THF}\right)$.

\section{Appendix A. Supplementary data}

CCDC 1527175-1527182 contain the supplementary crystallographic data for $\mathbf{2}, \mathbf{3}, \mathbf{4}, \mathbf{7}, \mathbf{8}, \mathbf{9}, \mathbf{1 0 a}$ and 10b. These data can be obtained free of charge via http://www.ccdc.cam.ac.uk/conts/retreiving/html, or from the Cambridge Crystallographic Data Centre, 12 Union Road, Cambridge CB2 1EZ, UK; fax: (+44) 1223-336-033; or e-mail: deposit@ccdc.cam.ac.uk. 


\section{Acknowledgements}

We gratefully acknowledge funding for this work from the National Science Foundation (CHE1229339 and CHE-1429086). PJH would like to thank the UMass Dartmouth Office of

Undergraduate Research for support. AK and DRJJ are grateful for support from the Urban Massachusetts Louis Stokes Alliance for Minority Participation. 


\section{References}

[1] C.C. Cummins, R.R. Schrock, W.M. Davis, Organometallics 11 (1992) 1452.

[2] R.R. Schrock, Acc. Chem. Res. 30 (1997) 9.

[3] R.R. Schrock, Acc. Chem. Res. 38 (2005) 955.

[4] B.M. Gardner, W. Lewis, A.J. Blake, S.T. Liddle, Organometallics 34 (2015) 2386.

[5] B.S. Newell, A.K. Rappé, M.P. Shores, Inorg. Chem. 49 (2010) 1595.

[6] D.M. King, F. Tuna, E.J.L. McInnes, J. McMaster, W. Lewis, A.J. Blake, S.T. Liddle, Science 337 (2012) 717.

[7] C. Morton, N.W. Alcock, M.R. Lees, I.J. Munslow, C.J. Sanders, P. Scott, J. Am. Chem. Soc. 121 (1999) 11255.

[8] A.C. Filippou, S. Schneider, G. Schnakenburg, Angew. Chem. Int. Ed. 42 (2003) 4486.

[9] Z. Duan, J.G. Verkade, Inorg. Chem. 34 (1995) 1576.

[10] A.F. Maddox, J.J. Davidson, T. Shalumova, J.M. Tanski, R. Waterman, Inorg. Chem. 52 (2013) 7811.

[11] S.M. MacMillan, J.M. Tanski, R. Waterman, Chem. Commun. (2007) 4172.

[12] S. Zahim, L.A. Wickramasinghe, G. Evano, I. Jabin, R.R. Schrock, P. Müller, Org. Lett. 18 (2016) 1570.

[13] K. Nomura, R.R. Schrock, W.M. Davis, Inorg. Chem. 35 (1996) 3695.

[14] M. Kol, R.R. Schrock, R. Kempe, W.M. Davis, J. Am. Chem. Soc. 116 (1994) 4382.

[15] G.E. Greco, R.R. Schrock, Inorg. Chem. 40 (2001) 3850.

[16] G.E. Greco, A.I. Popa, R.R. Schrock, Organometallics 26 (1998) 5591.

[17] C. Morton, K.M. Gillespie, C.J. Sanders, P. Scott, J. Organomet. Chem. 606 (2000) 14

[18] A. Almesäker, J.L. Scott, L. Spiccia, C.R. Strauss, Tetrahedron Letters 50 (2009) 1847.

[19] Y.S. Moroz, M.K. Takase, P. Müller, E.V. Rybak-Akimova, Acta Cryst. E67 (2011) o3421.

[20] R.H. Sànchez, A.M. Willis, S.-L. Zheng, T.A. Betley, Angew. Chem. Int. Ed. 54 (2015) 12009.

[21] V. Mdluli, P.J Hubbard, A. Kuznicki, J.A. Golen, A.L. Rheingold, D.R. Manke, Polyhedron 121 (2016) 264.

[22] T.M. Klaptöke, B. Krumm, R.Z. Moll, Naturforsch. B. 68 (2013) 735.

[23] D.A. Smith, S. Cramer, S. Sucheck, E. Skrzypczak-Jankun, Tet. Lett. 33 (1992) 7765.

[24] J.M. Rowland, G.J. Ibanez, M.M. Olmstead, M. Ruf, P.K. Mascharak, Acta Cryst. E57 (2001) o1001.

[25] A. Wünsche von Leupoldt, C. Förster, T.J. Fiedler, N.H. Bings, K. Heinze, Eur. J. Inorg. Chem. (2013) 6079. 
[26] D.M. King, F. Tuna, E.J.L. McInnes, J. McMaster, W. Lewis, A.J. Blake, S.T. Liddle, Science 337 (2012) 717.

[27] K.-Y. Shih, R.R. Schrock, R. Kempe, J. Am. Chem. Soc. 116 (1994) 8804.

[28] C.C. Cummins, R.R. Schrock, W.M. Davis Organometallics 11 (1992) 1452.

[29] E.P. Wildman, J.P.A. Ostrowski, D.M. King, W. Lewis, S.T. Liddle, Polyhedron (2016), http://dx.doi.org/10.1016/j/poly.2016.07.001

[30] Z. Duan, V.G. Young, Jr., J.G. Verkade, Inorg. Chem. 34 (1995) 2179.

[31] P. Roussel, N.W. Alcock, P. Scott, Inorg. Chem. 37 (1998) 3435.

[32] T.M. Klaptöke, B. Krumm, R.Z. Moll, Naturforsch. B 68 (2013) 735.

[33] Bruker (2014) APEX2, SAINT and SADABS. Bruker AXS Inc., Madison, Wisconsin, USA.

[34] G.M. Sheldrick, Acta Cryst. A64 (2008) 112.

[35] G.M. Sheldrick, Acta Cryst. C71 (2015) 3.

[36] O.V. Dolomanov, L.J. Bourhis, R.J. Gildea, J.A.K. Howard, H. Puschmann, J. Appl. Cryst. $42(2009) 339$. 


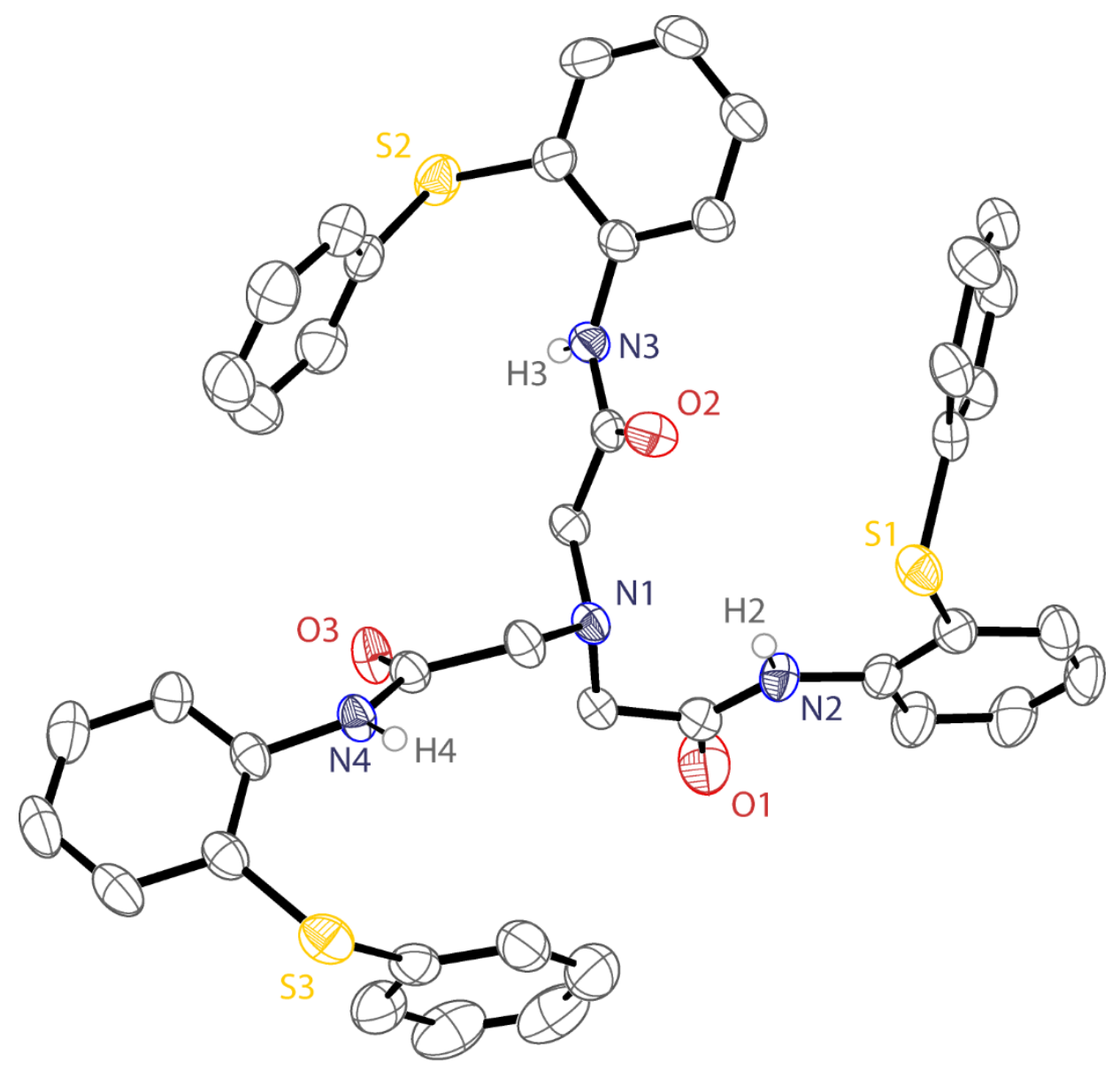

Figure 1, attached as pdf for review document. Quality image is included as an uploaded EPS file. 

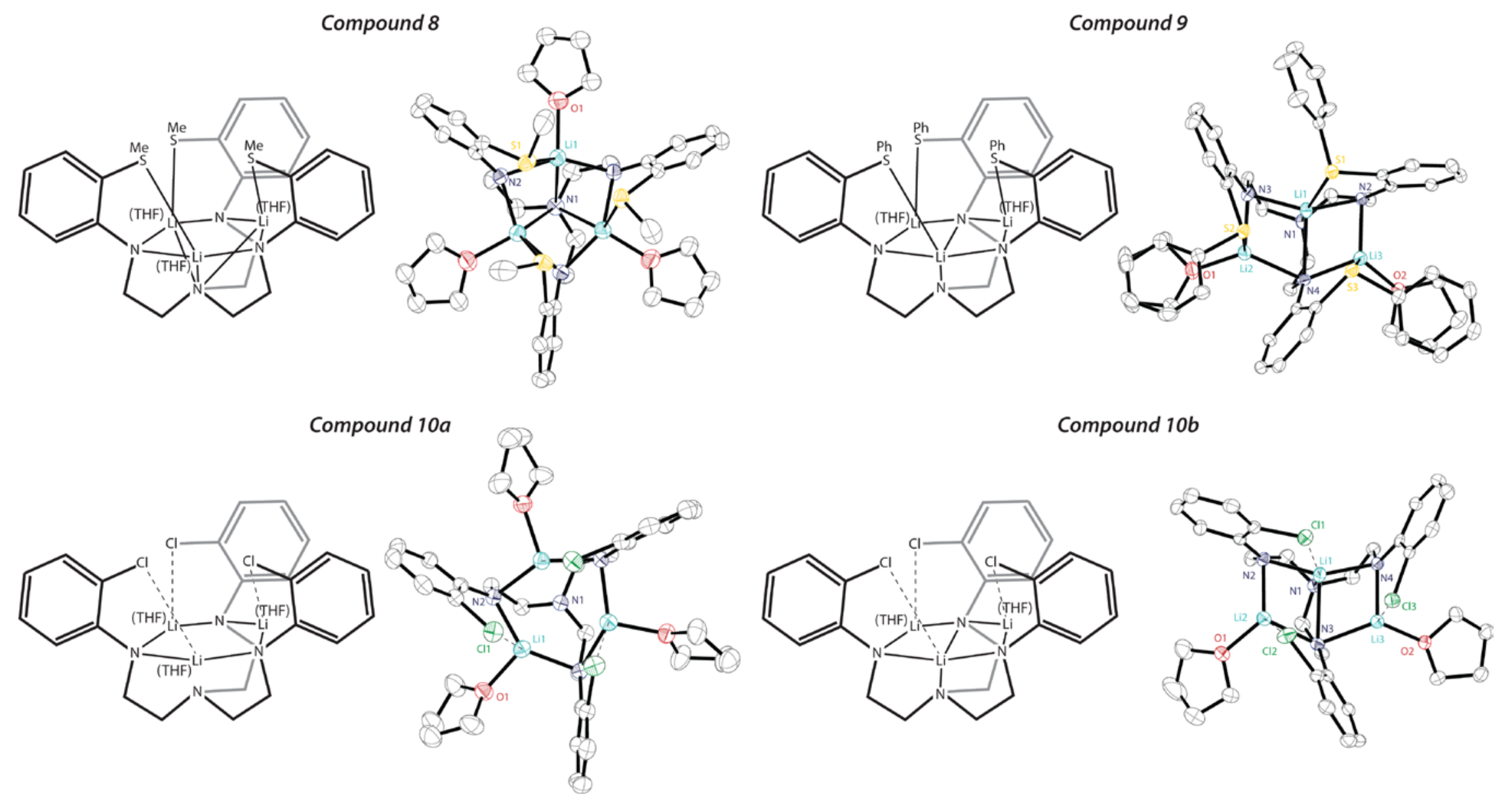

Figure 2, attached as pdf for review document. Quality image is included as an uploaded EPS file. 

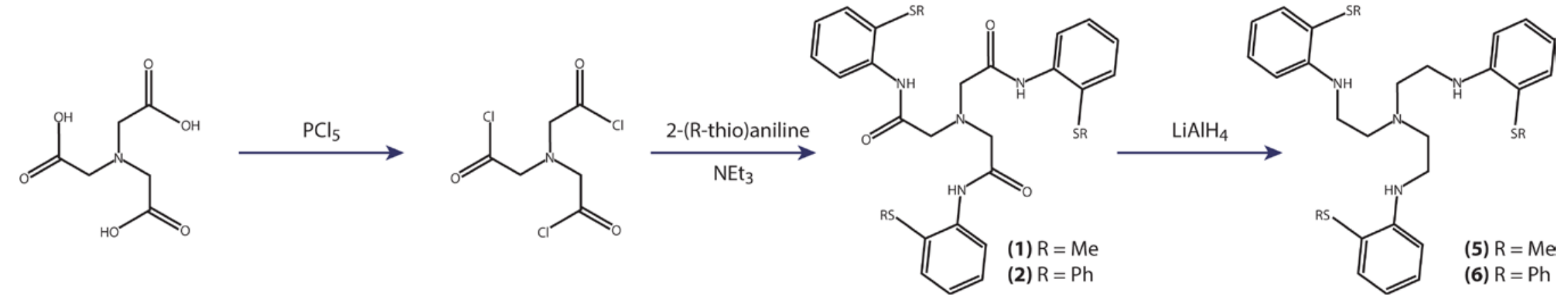

Scheme 1, attached as pdf for review document. Quality image is included as an uploaded EPS file. 


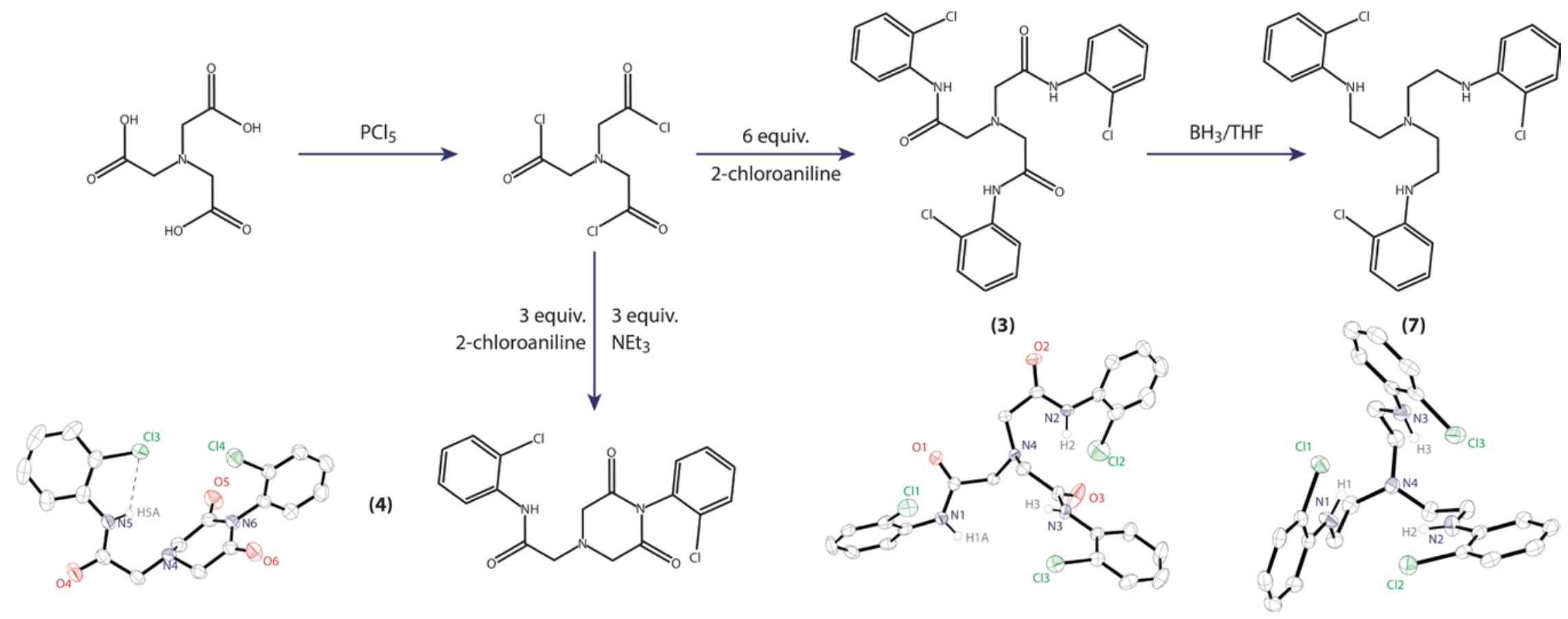

Scheme 2, attached as pdf for review document. Quality image is included as an uploaded EPS file. 


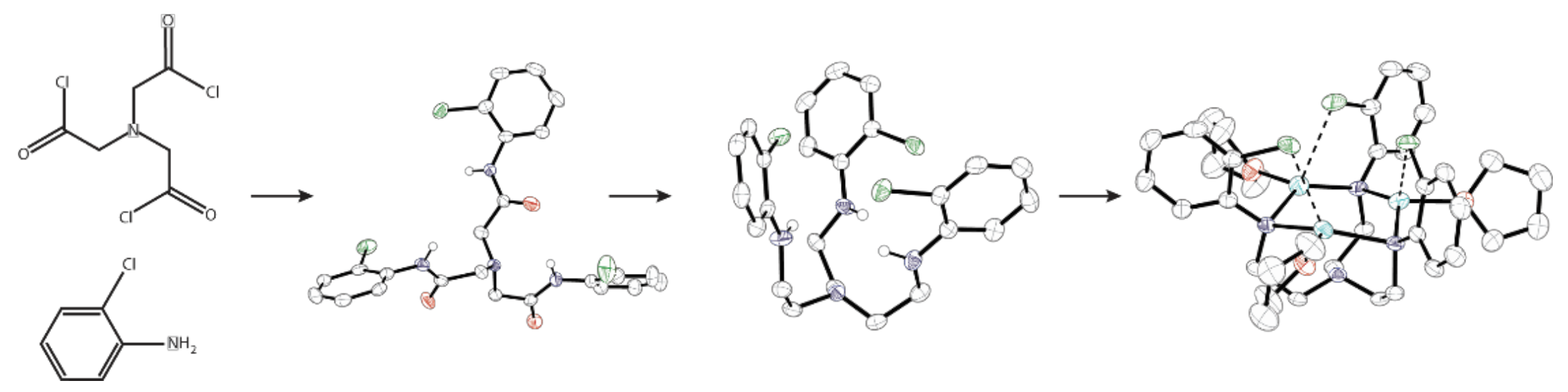

